\title{
Inheritance of SPAD chlorophyll meter reading and specific leaf area in four crosses of groundnut (Arachis hypogaea L.)
}

\author{
Pasupuleti Janila*, Surendra Singh Manohar, Abhishek Rathore and Shyam Narayan Nigam \\ International Crops Research Institute for the Semi-Arid Tropics (ICRISAT), Patancheru 502324
}

(Received: January 2014; Revised: May 2014; Accepted: June 2014)

\begin{abstract}
SPAD chlorophyll meter reading (SCMR) and specific leaf area (SLA) are important traits associated with water-useefficiency (WUE). Understanding their genetic nature and association with yield parameters enables their deployment in breeding programs for drought tolerance. The results obtained from the study conducted on six generations of four groundnut crosses showed significant additive effects for SCMR and SLA in all the crosses indicating possible gains through selection. Relative contribution of additive effects was high for both, SCMR (58 to 93\%) and SLA (63 to $91 \%$ ). The low heritability of SCMR and SLA indicates environmental influence on these traits. SCMR is positively associated with pod, kernel and haulm yield, while the association of SLA with them was negative. Combining trait-based approach using SCMR and SLA with empirical approach can be rewarding in groundnut breeding for drought tolerance.
\end{abstract}

Key words: WUE, SCMR, SLA, drought, additive effects, inheritance

Drought is a major abiotic constraint affecting groundnut production, with an annual estimated loss in production equivalent to US\$520 million and almost half of it can be recovered through genetic enhancement (Johansen and Nigam 1994). Breeding groundnut genotypes with enhanced water use efficiency (WUE) is an important strategy to overcome the challenges in water-limited conditions (Nautial et al. 2002; Nigam et al. 2005; Condon et al. 2004). Three key processes namely, moving more of the available soil water through the crop, improving crop transpiration efficiency and partitioning more of the achieved biomass into the harvested economic product (Rao et al. 2001) can be exploited in breeding for high WUE. Maintaining high chlorophyll density under water stress conditions is associated with high WUE in groundnut (Wright et al. 1994; Songsri et al. 2009). SPAD chlorophyll meter measures green colour intensity and is associated with chlorophyll density in groundnuts (Songsri et al. 2009; Lal et al. 2005). SLA is a measure of leaf thickness and low SLA groundnut genotypes produce higher dry matter under drought stress (Nautial et al. 2002). SLA is inversely associated with WUE (Samdur et al. 2002; Upadhyaya et al. 2011) and the association is stable (Suriharn 2011; Vasanthi et al. 2005) under severe drought. However, the said associations are not in complete agreement with some other findings (Nageswara et al. 2001; Cavalli 1952). SCMR and SLA are robust and low-cost surrogates of WUE, therefore understanding their genetic nature and association with yield parameters enables use of SCMR and SLA in breeding programs. The available inheritance studies of SCMR and SLA in groundnut show additive (Suriharn et al. 2011; Hayman 1958) and dominance gene effects with duplicate dominance epistasis (Warner 1952) for SLA, and additive (Warner 1952; Gromping 2007) and dominance effects (Warner 1952) for SCMR. SCMR is reported to be influenced by modifiers (Vasanthi et al. 2005).

The nature of inheritance of SCMR, SLA and yield parameters and their associations in four groundnut crosses namely, ICGV 87141 x ICGV 93291 , JL 24 x ICGV 86031, ICGV 99029 x ICGV 91284 and

*Corresponding author's e-mail: p.janila@cgiar.org

Published by the Indian Society of Genetics \& Plant Breeding, F2, First Floor, NASC Complex, PB\#11312, IARI, New Delhi 110012

Online management by indianjournals.com 
ICGV 07356 x ICGV 99029 were analysed. The six generations (parents, $\mathrm{F}_{1}, \mathrm{BC}_{1}, \mathrm{BC}_{2}$ and $\mathrm{F}_{2}$ ) of each cross were evaluated in a split-plot design with two replications during the 2010-11 postrainy season on a precision Alfisols field at ICRISAT, Patancheru, India. Crosses were assigned to main plots and generations to subplots. The parents and generations were sown on $60-\mathrm{cm}$ apart ridges with $10 \mathrm{~cm}$ distance between plants in a row. Recommended package of practices were adopted to raise a healthy crop.

Observations were recorded on 20 to 25 randomly selected plants of parents $\left(P_{1}\right.$ and $\left.P_{2}\right)$ and $F_{1}$ in each replication, all $875 \mathrm{~F}_{2}$ and $860 \mathrm{BC}_{1}$ and $\mathrm{BC}_{2}$ generation plants in all the four crosses. SCMR [using Minolta SPAD-502 meter (Minolta Camera Co. Ltd, Japan)) and SLA (LI-COR Area Meter - model 3000 (LI-COR Inc., Lincoln, NE, USA)] were recorded at 80 and 100 days after sowing (DAS) following the standard procedure (Nageswara 2001) along with yield parameters. Statistical analysis was performed using SAS 9.2. Six generations, the $P_{1}, P_{2}, F_{1}, F_{2}, B C_{1} F_{1}$ and $\mathrm{BC}_{2} \mathrm{~F}_{1}$ were used to fit the simple additivedominance model in the generation means approach. Joint scaling test (Cavalli 1952) was conducted. Six parameter model (Hayman 1958) was used to estimates the mean $(m)$, additive $(d)$ and dominance $(h)$ effects, and those caused by their interactions, $i, j$ and $l$. Broad sense heritability and narrow sense heritability were also estimated (Warner 1952). Relative importance of the gene effects was studied following modified method that is used extensively (Mather and Jinks 1982).

The t-test revealed significant differences between the parents of a cross for SCMR and SLA $(p<0.001)$ recorded at 80 as well as 110 DAS in all four and two crosses respectively. Parents were also significantly different for pod and kernel yield. The parents, ICGV 87141, ICGV 86031 and ICGV 99029 with high SCMR values and lower SLA values are water-use-efficient genotypes as SCMR is positively (Sheshshayee et al. 2006; Arunyanark et al. 2008) and SLA is negatively associated (Sheshshayee et al. 2006) with WUE. The difference between mean SCMR values between two parents of a cross range between 4 and 12 SPAD units, while mean SLA differences were between 22 and $56 \mathrm{~cm}^{2} \mathrm{~g}^{-1}$. The $F_{1}$ means were in between the parental means for SCMR and SLA indicating absence of dominance, while $F_{2}$ means transgressed the parental means. However segregants were not in desirable direction. In an earlier study, similar observation were made in $F_{1}$ and $F_{2}$
(Vasanthi et al. 2005). The segregants had low SCMR and high SLA, while the opposite would have resulted in segregants with enhanced WUE compared to parents. Heterosis was observed for pod, kernel and haulm yield.

The mean for all the traits in four crosses was significant indicating that all sources of variation were not explained by the present model (Table 1). Additive effects were significant for SCMR (at 80 and 110 DAS) and SLA (at 80 and 110 DAS) indicating the possibility of improving them through selection. Besides additive effects, dominance and additive $x$ additive effects were also significant for SCMR and SLA in some crosses. Additive effects for SLA (Lal et al. 2005; Nigam et al. 2001) and SCMR (Mather and Jinks 1982), other genetic effects were reported earlier (Upadhyaya et al. 2011). For both, SCMR and SLA, the additive $x$ additive $(I)$ and dominance $x$ dominance $(I$ ) effects are in opposite direction indicating duplicate and complementary epistatis according to Mather and Jinks (1982). Transgressive segregants for SCMR and SLA observed in $F_{2}$ generation may be the outcome of complementary gene effects. For pod and kernel yield, both, additive, dominance and interaction gene effects are significant (Table 1) thus, the progress through selection for pod and kernel yield will come from fixing of additive and additive $x$ additive effects. The relative contribution additive effects is higher for SCMR (5993\%) and SLA (63-91\%). Additive $x$ additive effects have large contribution to pod and kernel (43 and 65 $\%)$ and haulm yield (37-52\%) and hence it is possible to improve them by delaying their selection to higher generations.

Low heritability was observed in all the four crosses for SCMR (0.09 to 0.31$)$ as well as SLA (0.05 to 0.26$)$ and yield parameters $(<0.12)$ indicating influence of environment (Table 2). Consequently, the gains through selection may be slow. Broad sense heritability was reported to be high for SCMR (Nigam et al. 2011) and medium for SLA (Upadhyaya 2005) in previous studies. Narrow sense heritability was very low for SPAD and SLA. SCMR at 80 DAS showed significant positive association (0.3 to 0.74$)$ with SCMR at 110 DAS and similarly, the SLA at 80 DAS had significant positive correlation with SLA at 110 DAS (0.17 to 0.56$)$ indicating that one observation is sufficient to optimize time and resources. Earlier studies also showed that one observation of SLA and SCMR recorded after 60 DAS is as good as two or three observations (Nigam and Rupakula 2008). This 
Table 1. Estimates of nuclear genetic effects for different traits in four groundnut crosses

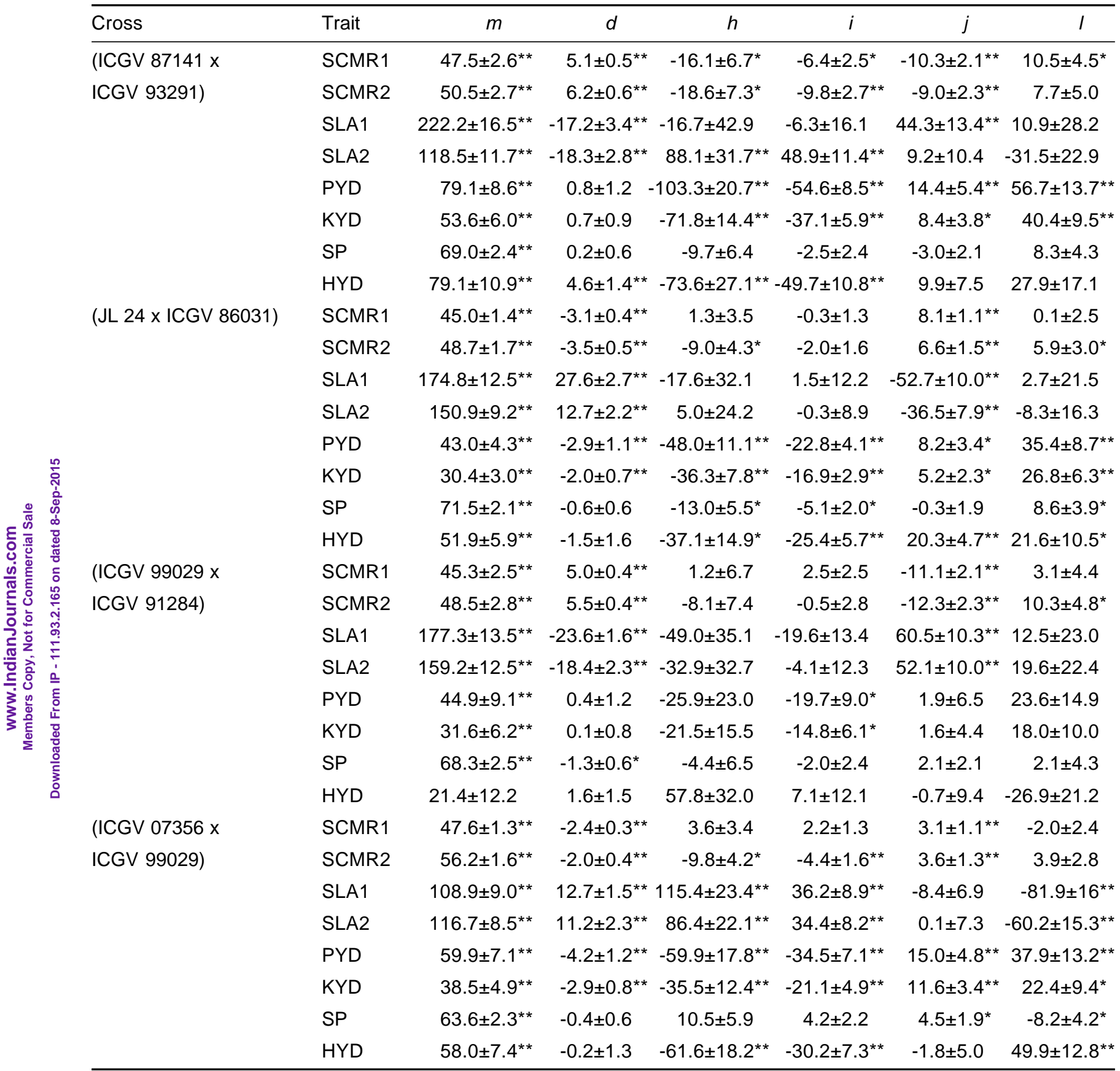

SCMR1 and SCMR2 = SPAD (Soil plant analysis development) chlorophyll meter reading at 80 and 110 DAS, respectively; SLA1 and SLA2 = Specific leaf area at 80 and $110 \mathrm{DAS}$, respectively; PYD = Pod yield per plant $(\mathrm{g}) ; \mathrm{KYD}=$ Kernel yield per plant $(\mathrm{g}) ; \mathrm{SP}=\mathrm{Shelling}$ percentage (\%); HYD = Haulm weight per plant $(\mathrm{g}) ;{ }^{*},{ }^{* *}$ significant at 0.05 , and 0.01 p levels, respectively; $m=$ mean; $d=$ additive; $h=$ dominance; $i=$ additive $\times$ additive $; j=$ additive $\times$ dominance and $I=$ dominance $\times$ dominance

gives flexibility to the breeders to incorporate selection of these traits in breeding scheme.

SCMR is inversely associated with SLA. The stable association of SCMR with WUE across varying water regimes (Arunyanark et al. 2009) and robustness of recoding SCMR enabled use of SCMR in breeding for drought tolerance. However, under severe drought, SLA was showed to be a more important contributor to WUE (Songsri et al. 2009). Therefore, both SCMR and SLA are considered in combination because of their association with WUE. SCMR is positively 
Table 2. Heritability in broad sense for various traits in four groundnut crosses

\begin{tabular}{lcccc}
\hline Traits & \multicolumn{4}{c}{ Heritability in broad sense } \\
\cline { 2 - 5 } & $\begin{array}{c}\text { Cross 1 (ICGV 87141 } \\
\text { ICGV 93291) }\end{array}$ & $\begin{array}{c}\text { Cross 2 (JL 24 } x \\
\text { ICGV 86031) }\end{array}$ & $\begin{array}{c}\text { Cross 3 (ICGV 99029 } x \\
\text { ICGV 91284) }\end{array}$ & $\begin{array}{c}\text { Cross 4 (9ICGV 07356 x } \\
\text { ICGV 99029) }\end{array}$ \\
\hline SCMR1 & 0.25 & 0.23 & 0.31 & 0.18 \\
SCMR2 & 0.29 & 0.21 & 0.31 & 0.09 \\
SLA1 & 0.05 & 0.23 & 0.26 & 0.17 \\
SLA2 & 0.19 & 0.09 & 0.17 & 0.15 \\
PYD & 0.13 & 0.12 & 0.10 & 0.11 \\
KYD & 0.11 & 0.12 & 0.10 & 0.10 \\
SP & 0.02 & 0.19 & 0.0 & 0.02 \\
HYD & 0.11 & 0.11 & 0.12 & 0.12 \\
\hline SCMR1 & 0.12 & & \\
\hline
\end{tabular}

SCMR1 and 2 = SPAD (Soil plant analysis development) chlorophyll meter reading at 80 and 110 DAS, respectively; SLA1 \& 2 = Specific leaf area at 80 and $110 \mathrm{DAS}$, respectively; PYD = Pod yield per plant $(\mathrm{g}) ; \mathrm{KYD}=$ Kernel yield per plant $(\mathrm{g}) ; \mathrm{SP}=\mathrm{Shelling}$ percentage $(\%)$ and HYD = Haulm weight per plant $(\mathrm{g})$

associated with yield parameters $(0.06$ to 0.32$)$ and SLA is negatively associated (-0.02 to -0.29$)$. However, higher SCMR and lower SLA values in a genotype may not have concomitant yield advantage although they are water-use-efficient.

Empirical approaches that measures pod yield under water stressed condition are used largely in groundnut breeding for drought tolerance (Nageswara and Nigam 2003), requiring huge resources and has large genotype $\mathrm{x}$ interaction for yield. A comparison between the selection gains through trait-based (using physiological traits associated with drought tolerance) and empirical approach has shown that the former is not superior to later in drought resistance breeding; nevertheless the integration of physiological traits or their surrogates would be advantageous in selecting genotypes which are more efficient water utilizers or better partition the photosynthates into economic yield (Nigam et al. 2005). Thus, a combination of trait-based and empirical approaches can be rewarding in groundnut breeding for drought tolerance. The present study shows probable gains in WUE through selection of its simple surrogate traits, SCRM and SLA as a consequence of their additive gene action in the four groundnut crosses.

\section{References}

Arunyanark A., Jogloy S., Akkasaeng C., Vorasoot N., Kesmala T., Nageswara Rao R. C., Wright G. C. and Patanothai A. 2008. Chlorophyll stability is an indicator of drought tolerance in peanut. J. Agron. Crop Sci., 194: 113-125.
Arunyanark A., Jogloy S., Vorasoot N., Akkasaeng C., Kesmala T. and Patanothai A. 2009. Stability of relationship between chlorophyll density and soil plant analysis development chlorophyll meter readings in peanut across different drought stress conditions. Asian J. Plant Sci., 8: 102-110.

Cavalli L. L. 1952. An analysis of linkage in quantitative inheritance. In: Quantitative Inheritance. (eds. E.C.R. Rieve, C.H. Waddington). HMSO, London. 135-144.

Condon A. G., Richards R. A., Rebetzke G. J. and Farquhar G. D. 2004. Breeding for high water-use efficiency. J. Exp. Bot., 55: 2447-2460.

Gromping U. 2007. Estimators of relative importance in linear regression based on variance decomposition. Am. Stat., 61: 139-147.

Hayman B. I. 1958. The separation of epistatic from additive and dominance variation in generation means. Heredity, 12: 371-390.

Johansen C. and Nigam S. N. 1994. Importance of drought stress and its alleviation in legumes. In: Selection for water-use efficiency in grain legumes (eds. G.C. Wright, R.C. Nageswara Rao). Technical Report No. 27, ACIAR, Canberra, Australia: 17-19.

Lal C., Hariprasanna K., Rathnakumar A. L., Basu M. S., Gor H. K. and Chikani B. M. 2005. Identification of water use efficient groundnut genotypes for rainfed situation through leaf morpho-physiological traits. Intl. Arachis Newsl., 24: 4-7.

Mather K. and Jinks J. L. 1982. Biometrical Genetics. 2nd edition, Chapman and Hall, London.

Nageswara Rao R. C., Talwar H. S. and Wright G. C. 2001. Rapid assessment of specific leaf area and leaf nitrogen in peanut (Arachis hypogaea L.) using a chlorophyll meter. J. Agron. Crop Sci., 186: 175-182. 
Nageswara Rao R. C. and Nigam S. N. 2003. Genetic options for drought management in groundnut. In: Management of Agricultural Drought: Agronomic and Genetic Options. Oxford \& IBH Publishing Co Pvt Ltd, New Delhi, India. 123-141.

Nautiyal P. C., Nageswara Rao R. C. and Joshi Y. C. 2002. Moisture-deficit-induced changes in leaf-water content, leaf carbon exchange rate and biomass production in groundnut cultivars differing in specific leaf area. Field Crops Res., 74: 67-69.

Nigam S. N., Chandra S., Sridevi K. R., Bhukta M., Reddy A. G. S., Rao R. C. N., Wright G. C., Reddy P. V., Deshmukh M. P., Mathur R. K., Basu M. S., Vasundhara S., Vindhiya Varman P. and Nagda A. K. 2005. Efficiency of physiological trait-based and empirical selection approaches for drought tolerance in groundnut. Ann. Appl. Biol., 146: 433-439.

Nigam S. N., Upadhyaya H. D., Chandra S., Nageswara Rao R. C., Wright G. C. and Reddy A. G. S. 2001. Gene effects for specific leaf area and harvest index in three crosses of groundnut (Arachis hypogaea L.) Ann. Appl. Biol., 139: 301-306.

Nigam S. N. and Rupakula A. 2008. Stability of soil plant analytical development (SPAD) chlorophyll meter reading (SCMR) and specific leaf area (SLA) and their association across varying soil moisture stress conditions in groundnut (Arachis hypogaea L.). Euphytica, 160: 111-117.

Rao R. C. N., Talwar H. S. and Wright G. C. 2001. Rapid assessment of specific leaf area and leaf nitrogen content in peanut Arachis hypogaea (L.) using a chlorophyll meter. J. Agron. Crop Sci., 189: 175-182.

Samdur M. Y., Singh A. L., Mathur R. K., Manivel P., ChiKani B. M., Gor H. K. and Khan M. A. 2000. Field evaluation of chlorophyll meter for screening groundnut (Arachis hypogaea L.) genotype tolerant to iron deficiency chlorosis. Current Sci., 79: 211214.

Sheshshayee M. S., Bindumadhava H., Rachaputi N. R., Prasad T. G., Udayakumar M., Wright G. C. and Nigam S. N. 2006. Leaf chlorophyll concentration relates to transpiration efficiency in peanut. Ann. Appl. Biol., 148: 7-15.

Songsri P., Jogloy S., Holbrook C. C., Kesmala T., Vorasoot N., Akkasaeng C. and Patanothai A. 2009. Association of root, specific leaf area and SPAD chlorophyll meter reading to water use efficiency of peanut under different available soil water. Agric. Water Management, 96: 790-798.

Suriharn B., Patanothai B. and Jogloy S. 2005. Gene effects for specific leaf area and harvest index in peanut (Arachis hypogaea L.). Asian J. Plant Sci., 4: 667672.

Upadhyaya H. D., Sharma S., Sube Singh and Murari Singh. 2011. Inheritance of drought resistance related traits in two crosses of groundnut (Arachis hypogaea L.). Euphytica, 177: 55-66.

Upadhyaya H. D. 2005. Variability for drought resistance related traits in the mini core collection of peanut. Crop Sci., 45: 1432-1440.

Vasanthi R. P., Seethala Devi G., Babitha M. and Sudhakar P. 2005. Inheritance of leaf chlorophyll content in groundnut. Indian J. Genet., 65: 196-198.

Warner J. N. 1952. A method for estimating heritability. Agron J., 44: 427-430.

Wright G. C., Nageswara Rao R. C. and Farquhar G. D. 1994. Water use ef?ciency and carbon isotope discrimination in peanut under water de?cit conditions. Crop Sci., 34: 92-97. 